THE APPLICATION OF JUST ADMINISTRATIVE ACTION IN THE SOUTH AFRICAN ENVIRONMENTAL GOVERNANCE SPHERE: AN ANALYSIS OF SOME CONTEMPORARY THOUGHTS AND RECENT JURISPRUDENCE

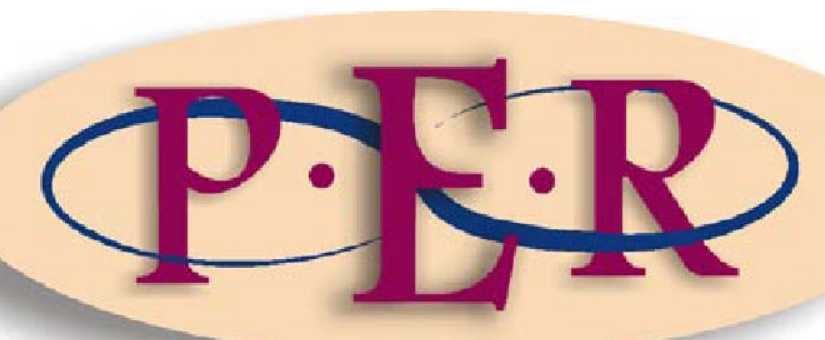

2004 VOLUME 7 No 2 


\title{
THE APPLICATION OF JUST ADMINISTRATIVE ACTION IN THE SOUTH AFRICAN ENVIRONMENTAL GOVERNANCE SPHERE: AN ANALYSIS OF SOME CONTEMPORARY THOUGHTS AND RECENT JURISPRUDENCE
}

\author{
LJ Kotzé*
}

During the past ten years of democracy in South Africa, administrative law, ${ }^{1}$ and administrative justice $^{2}$ has become increasingly important in the realm of environmental law. ${ }^{3}$ It is correctly observed in this regard that the effectiveness of environmental law not so much relates to the content thereof, but rather to lack of

* Senior Lecturer, Faculty of Law, North-West University, Potchefstroom Campus. My thanks to Willemien du Plessis and Anel du Plessis, Faculty of Law, North-West University, Potchefstroom Campus, for their helpful comments on an earlier draft of this article. The views expressed herein and any errors are my own.

1 Various definitions of administrative law exist. See for instance Devenish, Govender and Hulme Administrative Law 7-8. Administrative law is however increasingly regarded as also applying to public authorities in a broad and strict sense. For the purpose of this article, administrative law is defined as that branch of public law: "...regulating the activities of bodies that exercise public powers or perform public functions, irrespective of whether those bodies are public authorities in a strict sense". See in this regard Hoexter and Lyster Constitutional and Administrative Law 2. Administrative law emphasises one particular branch of the state system, namely that of public administration, and more particularly administrative activities by the state. In this context, administrative law describes what the administration must do and what it may do. It also provides for remedies in the case of maladministration. The actions of some private institutions, or bodies, may also qualify as administrative actions, even though these bodies and institutions are not strictly speaking part of the broader public administration domain. See in this regard Hoexter and Lyster Constitutional and Administrative Law 2-4; Glazewski Environmental Law 99; and Devenish, Govender and Hulme Administrative Law 83-85.

2 S 33 of the 1996 Constitution is known as the 'just administrative action' clause. Administrative justice is defined for the purpose of this article as: "...that part of public law which regulates the exercise of administrative action, that is the exercise of public powers and the performance of public functions by organs of state, which falls within the constitutional right to just administrative action laid down in s 33 of the Constitution." Burns Administrative Law 9.

The definition of just administrative action, or administrative justice, oddly correlates with the definition of administrative law explained in $n 1$ above. The only logical explanation for this, is perhaps because administrative justice and administrative law are equated in terms of their scope, nature, aims and application possibilities. Be this as it may, one can at the very least argue that administrative law is necessary to realise administrative justice in SA. Devenish, Govender and Hulme Administrative Law 11, 14-17.

3 Glazewski Environmental Law 97-99. Environmental law is defined for the purpose of this article as: "The amalgamation of norms, standards, legislation, administrative regulation, and international law that aims to regulate human activities and natural resources in a sustainable fashion, by way of environmental management and environmental governance" (adapted from Glazewski Environmental Law 11). It is noteworthy that the definition of environmental law specifically includes administrative regulation, hence supporting the argument in par 2 and 3 
adequate enforcement of, what is generally regarded, as a modern and progressive environmental law regime. ${ }^{4}$

Enforcement of environmental law arguably relates to administrative actions and administrative decision-making processes and procedures carried out by relevant environmental authorities, within the more general realm of environmental administration and environmental governance. ${ }^{5}$ One of the aspects that are regulated by environmental governance and administration, is infrastructural development, which in most instances, may have a detrimental effect on the environment. Infrastructural development activities are important for, inter alia, economic progress and the improvement of socio-economic conditions, and depend to a large extent on administrative decision-making by environmental authorities. ${ }^{6}$ It is however noteworthy that development is sometimes hampered by inefficient and delayed decision-making processes by environmental authorities, which may adversely affect the developer. ${ }^{7}$ For a balance to be created between the rights of the developer and the duties on environmental authorities to realise the content and objectives of constitutional and environmental legislation, it is accordingly necessary to investigate the issue of administrative justice in the context of environmental administration and governance.

It is argued in this article that there exists a close relationship between administrative implementation and decision-making, and a right to an environment that is not harmful to peoples' health or well-being. ${ }^{8}$ By investigating some of the constitutional rights of the developer, as well as the concept of administrative justice, this article further argues that environmental governance and administration, which should ideally be based on administrative justice, may be beneficial to individuals who carry out activities that may adversely impact on the environment. The provisions of the Promotion of Administrative Justice Act 3 of 2000 (hereafter the PAJA) are also reflected on, in order to indicate the relevance of some provisions of this act for an

below that administrative implementation and decision-making are paramount for the efficient implementation of environmental law in SA.

4 De Waal, Currie and Erasmus Bill of Rights Handbook 402.

5 Hoexter and Lyster Constitutional and Administrative Law 2.

6 Kotzé and Van der Walt 2003 SAJELP 42, 63-66.

7 Kotzé and Van der Walt 2003 SAJELP 42.

8 S 24 of the 1996 Constitution. See par 2 below for a further discussion. 
aggrieved developer whose right to administrative justice has been infringed. The importance and relevance of administrative justice in the context of environmental governance are illustrated by reflecting on two recent judgments that, although not specifically dealing with administrative justice in the context of environmental administration, may provide some guidance as to the future application of administrative justice in the realm of environmental governance and administration. In discussing these judgments, specific emphasis is placed on the right to administrative justice, and the possible effect of the judicial interpretation of administrative justice on other rights of the developer that correlate with the section 33 constitutional right. ${ }^{9}$

\section{Section 24 of the 1996 Constitution and administrative implementation}

Section 24 of the 1996 Constitution states that:

Everyone has the right-

(a) to an environment that is not harmful to their health or well-being; and

(b) to have the environment protected, for the benefit of present and future generations, through reasonable legislative and other measures that-

(i) prevent pollution and ecological degradation;

(ii) promote conservation; and

(iii) secure ecologically sustainable development and use of natural resources while promoting justifiable economic and social development.

Section 24 reflects characteristics of both a classical fundamental human right and a socio-economic right. ${ }^{10}$ The first generational character of the right is embodied in section 24(a), whilst the socio-economic character of the right is found in section 24(b). ${ }^{11}$ Section 24(b) strongly articulates the vertical operation of the environmental right, which supports the contention that the application of the right also relates to

9 These rights include the right to dispute settlement, the right to access to information, and the right to a wide legal standing. See par 4 below for a detailed discussion.

10 De Waal, Currie and Erasmus Bill of Rights Handbook 403-405.

11 Glazewski Environment 413. 
administrative implementation of this right by way of reasonable legislative and other measures. $^{12}$

The realisation of section 24 may be regarded as a regulatory function belonging to government. ${ }^{13}$ Government in this context includes, inter alia: national, provincial and local spheres; ${ }^{14}$ the various line functionaries in each sphere; ${ }^{15}$ and government officials functioning in these spheres and line functions. It may furthermore be deduced that there is a relationship between the enforcement of the environmental right and administrative implementation. Implementation in this context is a very broad term which arguably includes the enforcement of legislation, making of subsidiary rules, and formulation of policy. ${ }^{16}$ Various actors are involved with the implementation of environmental law. These include public authorities, employees of public authorities and government departments, and the public service or administration. ${ }^{17}$ More pertinent in this regard however is that:

... the public service is under a constitutional duty loyally to execute 'the lawful policies of the government of the day', and it does this chiefly by implementing legislation. ${ }^{18}$

The enforcement of provisions pertaining to environmental authorisations, such as water use licences provided for in chapter 4 of the National Water Act 36 of 1998 (hereafter the NWA), serves as an example of an instance where administrative implementation through environmental administration, is executed by relevant departments of government, in this case the Department of Water Affairs and Forestry (hereafter DWAF). ${ }^{19}$ Water is a natural resources as contemplated in section 24(b)(iii) of the 1996 Constitution. Hence, there is an obligation on government to 'secure

12 S 8 of the 1996 Constitution states that a "...provision of the Bill of Rights binds a natural or a juristic person if, and to the extent that, it is applicable, taking into account the nature of the right and the nature of any duty imposed by the right". Hence, it is argued in addition, that s 24 also has a horisontal operation which makes it applicable between individuals themselves and not only between the state and individuals. See also Glazewski Environmental Law 88-89.

13 For a detailed discussion on the administration, implementation and enforcement of environmental law in SA, see Glazewski Environmental Law 127-157.

14 S 40(1) of the 1996 Constitution.

15 Governmental line functionaries in environmental context may include, inter alia, the Department of Environmental Affairs and Tourism; the Department of Water Affairs and Forestry; the Department of Minerals and Energy; and the South African Heritage Resources Agency.

16 Hoexter and Lyster Constitutional and Administrative Law 7.

17 Ibid.

18 Ibid.

19 See also the example discussed in par 3 below. 
ecologically sustainable development' of this natural resource through, inter alia, the implementation of water use licence conditions which set limits within which water can be used. Such implementation, or in other words, the issuing of water use licences, may be done by way of, inter alia, environmental administration and governance. It is argued further that implementation may be done by way of 'reasonable legislative and other measures' contemplated in section 24(b) of the 1996 Constitution. In this instance, 'reasonable legislative and other measures' may include the provisions of the NWA.

The relationship between section 24 and administrative implementation is furthermore evident from the argument that the most obvious feature of potential environmental impacts and pollution problems is that they affect both public health and resources, which are public goods. ${ }^{20}$ The risk of pollution often arises from otherwise legitimate activities within society, such as the accommodation of waste in the environment in a manner which may impact on health and/or the integrity of resources. The implication is that the control of potential impacts on humans and the environment is typically a regulatory function, since society must be protected from pollution by government action. $^{21}$ Administrative implementation is therefore necessary to comprehensively and adequately give effect to, and realise the aims of, section 24 through the execution of necessary government actions.

It is furthermore argued that there exists a close link between environmental governance and environmental administration and implementation. Environmental governance is a relatively novel term in South African law. It can be defined as "...the

20 Bosman Waste Disposal 28.

21 Ibid. The argument that the control of potential impacts on humans and the environment is typically a regulatory function, is strengthened by the notion of the social welfare state, in which the state plays a "...positive and interventionist role in socio-economic regeneration and the welfare of citizens". Hoexter and Lyster Constitutional and Administrative Law 15. Although SA can not be regarded as a typical social welfare state, the state has in the past, and continues to play, an active interventionist role. Hoexter and Lyster Constitutional and Administrative Law 15. As pollution and environmental degradation continue to intensify, one might reasonably expect that environmental regulation through intervention may become all the more significant in SA. This may have a direct bearing on the relevance of administrative justice in SA, because as environmental administration and regulation increase, so may administrative justice become increasingly important. See also Devenish, Govender and Hulme Administrative Law 27. Burns specifically emphasises the interventionist role of the welfare state in environmental context by stating that "...the state takes active steps to improve the state economy by stimulating development, protecting and beautifying the environment and assisting people to enrich their lives". Burns Administrative Law 7. 
collection of legislative, executive and administrative functions, processes and instruments used by any organ of state to ensure sustainable behaviour by all as far as governance activities, products, services, processes and tools are concerned." ${ }^{22}$ Hence it may be said that government can realise the objectives of section 24 , inter alia, by way of administrative implementation, or environmental governance. Administrative implementation and enforcement of environmental law may be done by way of judicial measures and administrative measures. ${ }^{23}$ The focus of this article is on administrative measures which are applied by the executive branch of government. ${ }^{24}$ These measures include, inter alia, subordinate legislation, regulations, statutory directives, authorisation requirements and abatement notices. ${ }^{25}$ The mandate for this administrative implementation, or governance, will in this case be reasonable legislative and other measures, which provide the impetus for action on behalf of government. Whilst governance refers to the broader activities or functions of the state, environmental administration, or implementation, entails the specific execution of governance functions in terms of section 24 of the 1996 Constitution and environmental sectoral legislation. The provisions of section 24 of the 1996 Constitution thus set the framework for the administration of environmental law, by providing the impetus for implementation and governance through administrative functions within the broader context of environmental legislation. ${ }^{26}$ The relationship

22 Nel and Du Plessis "Integrated Environmental Management" 89.

23 Judicial measures include criminal sanctions, civil sanctions, judicial review and interdicts which are normally applied by the judiciary. Glazewski Environmental Law 143.

24 This article specifically focuses on administrative measures, or acts, employed by environmental authorities. Apart from judicial review which may be regarded as a remedy in the case of maladministration, judicial measures are accordingly not discussed. Administrative acts include "...those acts by which the administration creates, alters or terminates individual administrative law relationships [by way of finding the] most expedient and desirable solution in the public interest". Devenish, Govender and Hulme Administrative Law 103.

25 Glazewski Environmental Law 143.

26 It is even observed in this regard that the 1996 Constitution, which includes the environmental right, constitutes one of the sources of administrative law. Original and delegated legislation, such as, inter alia, the National Water Act 36 of 1998, the National Environmental Management Act 107 of 1998, the Environment Conservation Act 73 of 1989, as well as various provincial environmental acts and environmental by-laws, also serve as sources of administrative law. See further Hoexter and Lyster Constitutional and Administrative Law 16-18. The mere fact that environmental legislative and constitutional provisions act as primary sources of administrative law, justifies the contention that there is indeed a close correlation and relationship between administrative law, administrative justice and the environment. It should also be noted that administrative practice may serve as a source of administrative law. Public officials may therefore in certain instances rely on established practice within the administration to justify a certain administrative action. This is however more the exception than the rule, and it is envisaged that where the right to administrative justice has been infringed by, for example an unreasonable delay in the environmental authorization process, courts will arguably not attach great significance to this source. See Devenish, Govender and Hulme Administrative Law 35-49, 58-59. 
between environmental governance, environmental administration, environmental implementation and administrative justice, is discussed in further detail hereafter. ${ }^{27}$

\section{The developer, the environment and administration}

Glazewski ${ }^{28}$ observes that "...environmental law can be described as administrative law in action". ${ }^{29}$ He substantiates this contention by adding that the reason for this-

... is because administrative law is essentially concerned with administrative decision-making and environmental conflicts invariably turn on the exercise of administrative decision-making powers. ${ }^{30}$

In other words, the administration of environmental law lies mainly with the state administration which includes, inter alia, state structures, processes and officials. The sheer scope of administrative law, also justifies the relationship and interplay between environmental law and administrative law. It is observed in this regard that the scope of administrative law is quite broad and includes, inter alia, activities relating to the granting of licences, town-planning, other infrastructural development activities, and also the protection of the environment. ${ }^{31}$

Based on the foregoing, it is envisaged that a developer would approach a relevant environmental authority when undertaking any development that might fall within the ambit of relevant provisions of environmental legislation. Some practical examples would include for instance: the establishment of a golf estate in an environmentally sensitive coastal area, flooding of valleys for the building of dams to ensure freshwater supply, establishment of mining structures, and building of low-cost

27 See par 3 below.

28 Glazewski Environmental Law 97.

29 It is interesting to note that administrative law has been described as 'the state in motion'. Emphasis is accordingly placed on the functional element rather than the structural element of government. See in this regard Hoexter and Lyster Constitutional and Administrative Law 10. In concurring with Glazewski, one can thus argue that environmental law holds as an essential element, the functions of government insofar as it pertains to the execution of state actions, in order to realise the content of s 24 of the 1996 Constitution and environmental law in general. The premise of this argument is the equation between environmental law and administrative law that Glazewski puts forward. Glazewski Environmental Law 97.

30 Glazewski Environmental Law 97.

31 Hoexter and Lyster Constitutional and Administrative Law 14. 
housing structures to address the plight of the homeless. The foregoing represents infrastructural development activities, which can only commence if the necessary authorisations in terms of environmental sectoral legislation are obtained from the relevant environmental authority. ${ }^{32}$ These authorities may include amongst others, the Department of Environmental Affairs and Tourism (hereafter DEAT), the DWAF, the Department of Minerals and Energy, and various provincial and local departments entrusted with environmental governance functions.

A typical example of an environmental authorisation is a record of decision in terms of an environmental impact assessment which must be obtained under sections 21, 22, 23 and 26 of the Environment Conservation Act 73 of 1989 (hereafter the ECA) before an activity identified under R 1182, R 1183 and R 1184, published in Government Gazette 18261 of 5 September 1997 is undertaken. ${ }^{33}$ Section 21 states that the minister of the DEAT may identify those activities that may have a detrimental effect on the environment. These activities include, but are not limited to, activities relating to land use and land transformation; water use and water disposal; resource removal, including natural living resources; resource renewal; agricultural processes; industrial processes; transportation; energy generation and energy distribution; waste and sewage disposal; chemical treatment; and recreation. ${ }^{34}$ Before such an activity is to be undertaken, the developer must conduct an environmental impact assessment and only after consideration by the relevant authority, will an authorisation in the form of a record of decision be issued or not. ${ }^{35}$

32 This sectoral legislation includes, inter alia, the National Water Act 36 of 1998, the Water Services Act 108 of 1997, the Marine Living Resources Act 18 of 1998, the National Forests Act 84 of 1998, the National Heritage Resources Act 25 of 1999, the National Nuclear Energy Regulator Act 47 of 1999, the National Veld and Forest Fire Act 101 of 1998, the Nuclear Energy Act 46 of 1999, and the Mineral and Petroleum Resources Development Act 28 of 2002. Cf Glazewski Environmental Law 152-154 for a further discussion on permits, licensing, scheduling, abatement notices, and directives.

33 The provisions of the ECA relating to environmental impact assessment should be read together with R 1182, R 1183 and R 1184, published in GG 18261 of 5 September 1997. It is envisaged that the environmental impact assessment procedure will in future resort under the provisions of the NEMA. The draft environmental impact assessment regulations were distributed for comment at the time of writing. These regulations are not yet in force, and will therefore not be discussed for the purpose of this article. For a detailed discussion of administrative justice in terms of the current environmental impact assessment process, see Kotzé and Van der Walt 2003 SAJELP 39-66.

$34 \mathrm{~S} 21(2)(\mathrm{a})-21(2)(\mathrm{k})$ of the ECA.

35 S 22(1) states that: "No person shall undertake an activity identified in terms of s 21(1) or cause such an activity to be undertaken except by virtue of a written authorisation issued by the Minister or by a competent authority or local authority or an officer..." 
It is clear in this instance that a developer who seeks to undertake any of the above activities, will be subject to administrative decision-making procedures. The status of the developer may invariably be affected during the processing of the development application, because in order to exercise its governing function, the state bears and enforces state authority when having to approve of a development activity. The individual may consequently be placed in an inferior position vis-à-vis the state. ${ }^{36}$ In this context, the developer arguably would want to have his or her application processed as soon as possible due to, for example, financial considerations. ${ }^{37}$ Any delays during the administrative decision-making process may, however, affect his or her financial position by infringing his or her right to administrative action that is lawful, reasonable and procedurally fair. The question accordingly arises, whether the developer has certain rights on the basis of which he or she can be protected from unlawful, unreasonable, and procedurally unfair administrative action.

\section{The constitutional rights of an aggrieved developer}

\subsection{The right to just administrative action}

Based on the foregoing, it is argued that the developer has certain rights when it comes to administrative decision-making by the relevant environmental authority. ${ }^{38}$ With reference to the hypothetical scenario in paragraph 3 above, it must be clarified first and foremost that the developer does not necessarily have a right to commence an

36 Devenish, Govender and Hulme Administrative Law 85.

37 It is generally accepted that time and financial constraints, resulting from compliance with authorisation requirements, place a burden on developers, and may even have a negative effect on the vision for sustainable development enumerated in s 24 of the 1996 Constitution. The purpose of authorisations is arguably not to strain development by unduly withholding development approval, but rather to guide development on a road towards sustainability. The foregoing describes a fine balance between the rights of the developer and the duties of the relevant environmental authority to give effect to environmental legislation and constitutional provisions. For this balance to be created, it is argued that administrative decision-making must be based on the principle of administrative justice. See for a detailed discussion Kotzé and Van der Walt 2003 SAJELP 39-66.

38 It is argued that the constitutionalisation of administrative law gave rise to the emergence of a rights-based approach to administrative law in general and administrative justice in particular. This new approach therefore supports the argument that a developer may have certain rights in terms of administrative implementation in environmental context. Devenish, Govender and Hulme Administrative Law 6 and Burns Administrative Law 53-75. 
infrastructural development for the sake of financial gain. ${ }^{39}$ Rather, the developer has a right to, inter alia, just administrative action that is lawful, reasonable and procedurally fair. ${ }^{40}$ This right is provided for by section 33 of the 1996 Constitution which states that:

(1) Everyone has the right to administrative action that is lawful, reasonable and procedurally fair.

(2) Everyone whose rights have been adversely affected by administrative action has the right to be given written reasons.

(3) National legislation must be enacted to give effect to these rights, and must -

(a) provide for the review of administrative action by a court or, where appropriate, an independent and impartial tribunal;

(b) impose a duty on the state to give effect to the rights in subsections (1) and (2); and

(c) promote an efficient administration.

Section 33 essentially embraces the concept of administrative justice. Administrative justice aims to, inter alia, ensure good governance and administration, ensure fair dealing in administrative context, enhance protection of the individual against abuse of state power, promote public participation in decision-making, and strengthen the notion that public officials are answerable and accountable to the public they are meant to serve. ${ }^{41}$ In sharp contrast with the past regime of parliamentary sovereignty, it is argued that individuals have certain rights, privileges and liberties in the context of an administrative relationship. These rights are enumerated in, inter alia, section 33 of the 1996 Constitution. Where the public administration consequently acts in an unlawful manner and contrary to public interest when administering its functions, the state may be held liable in terms of section 33 and the provisions of the PAJA. ${ }^{42}$

There is a close relationship between administrative justice and the term "administrative action". The meaning of "administrative action" in section 33(1), is demarcated to include actions of an administrative nature which are taken by bodies

39 As far as could be ascertained, no explicit right to development exists in South African law. Kotzé and Van der Walt 2003 SAJELP 40.

$40 \mathrm{~S} 33$ of the 1996 Constitution.

41 Devenish, Govender and Hulme Administrative Law 14-16.

42 Ibid 85 and par 5 below. 
that exercise public power. ${ }^{43}$ These actions include adjudicative administrative decisions and governmental administration through regulation. ${ }^{44}$ Administrative action should however also be afforded a "...wide and value-coherent interpretation rather than a narrow one". ${ }^{45}$ If this approach is followed, administrative action may also in some instances include certain private actions performed by private bodies. ${ }^{46}$ Administrative action also covers regulations, legislation and administrative decisions made by the executive branch of government, and would necessarily include environmental legislation and regulations, such as the ECA and its accompanying regulations in terms of which environmental impact assessments are to be conducted. $^{47}$

It is evident from section 33 that administrative action should be lawful, reasonable and procedurally fair. ${ }^{48}$ Procedural fairness relates to the principles of natural justice that include, inter alia, the principles of audi alteram partem and nemo iudex suo causa. ${ }^{49}$ Whilst procedural fairness relates to the procedural aspect of natural justice, reasonableness relates to the substantive element of natural justice, by which a court is afforded the opportunity to investigate the justification of administrative actions. ${ }^{50}$ Where someone's right to administrative justice has been adversely affected, that person furthermore has a right to be given written reasons. ${ }^{51}$ These reasons must be adequate, proper, relevant, and must relate to the administrative action under scrutiny. ${ }^{52}$ The provisions on the right to be given written reasons are arguably meant to promote a more transparent, public-participatory, democratic and efficient administration.

43 See also par 5.1 below, where administrative action is discussed in greater detail.

44 Devenish, Govender and Hulme Administrative Law 126.

45 Ibid 127.

46 Ibid126-127. The focus of this article is however on administrative actions performed by environmental governmental authorities and would hence exclude those actions performed by such private bodies.

47 Ibid 128. See also par 3 above.

48 See for an insightful and in-depth discussion on lawfulness, reasonableness and procedural fairness, Hoexter and Lyster Constitutional and Administrative Law 125-241.

49 See the whole of s 3 of the PAJA, and Devenish, Govender and Hulme Administrative Law 129.

50 Devenish, Govender and Hulme Administrative Law 130-131.

51 See the whole of s 5 of the PAJA, and Hoexter and Lyster Constitutional and Administrative Law 242-254.

52 Devenish, Govender and Hulme Administrative Law 133. 
The provisions on administrative justice should be read together with the provisions of section 195(1) and section 195(2) of the 1996 Constitution that establish basic values and principles according to which the public administration must be executed. ${ }^{53}$ It is stated in this regard that the public administration must be governed by the general democratic values and principles enshrined in the 1996 Constitution. Moreover, a number of specific principles are provided for, which advocate that: a high standard of professional ethics must be promoted and maintained; efficient economic and effective use of resources must be promoted; public administration must be development-oriented; services must be provided impartially, fairly, equitably and without bias; people's needs must be responded to, and the public must be encouraged to participate in policy-making; public administration must be accountable; transparency must be fostered by providing the public with timely, accessible and accurate information; good human-resource management and careerdevelopment practices to maximise human potential, must be cultivated; and public administration must be broadly representative of the South African people, with employment and personnel management practices based on ability, objectivity, fairness, and the need to redress the imbalances of the past to achieve broad representation. ${ }^{54}$ It is explicitly stated that these principles apply to all organs of state as well as state administration in every sphere of government. ${ }^{55}$

It is clear from the above that an individual, who seeks for example authorisation for a development activity that may adversely affect the environment, has certain rights based merely on the provisions of section 33. Broadly speaking, these rights fall within the ambit of the more generally-termed right to administrative justice which should be read together with section 195 of the 1996 Constitution. As separate components of this general right, the developer in particular has the right to written reasons, and administrative action that should be based on the principles of natural justice which include reasonableness and fairness. Because of these rights, it is thus clear that the developer does not stand wholly at the mercy of the public administration. The public administration may indeed be held liable and accountable

53 Kotzé and Van der Walt 2003 SAJELP 50-51.

54 S 195(1) of the 1996 Constitution.

55 S 195(2) of the 1996 Constitution. 
for an infringement of any of these rights, and may in addition be obliged to rectify any infringement.

\subsection{The right to dispute settlement}

The right to just administrative action is reinforced and extended by the right to have disputes settled by a court or another independent forum. ${ }^{56}$ Section 34 of the 1996 Constitution states that:

Everyone has the right to have any dispute that can be resolved by the application of law decided in a fair public hearing before a court or, where appropriate, another independent and impartial tribunal or forum.

It is trite that this right cannot be invoked where a developer applies for an environmental authorisation in terms of environmental legislation. For the protection of section 34 to become operative and applicable, it is necessary that a dispute should exist. A developer who is accordingly of the opinion that his or her authorisation application is being unreasonably delayed or denied unlawfully, can approach a court of law or independent tribunal or forum, to have the legal dispute that arose because of the delay or denial, adjudicated. ${ }^{57}$ The right to have a dispute settled has even greater application possibilities, which may extend the rights of any aggrieved developer. This is because this right further includes: a right of access to a court or independent forum; the requirement that courts and forums should be independent and impartial; and the requirement that the dispute be decided in a fair and public hearing. ${ }^{58}$

\subsection{The right of access to information}

The right of access to information which is currently regulated by the Promotion of Access to Information Act 2 of 2000 (hereafter the PATIA), ${ }^{59}$ is enumerated in section

56 S 34 of the 1996 Constitution.

57 De Waal, Currie and Erasmus Bill of Rights Handbook 555.

58 See De Waal, Currie and Erasmus Bill of Rights Handbook 554-580, for an in-depth discussion.

59 Apart from the discussion in par 5 below, the PATIA is not discussed in detail for the purpose of this article. For a detailed discussion of the PATIA, see De Waal, Currie and Erasmus Bill of Rights Handbook 527-553, Devenish, Govender and Hulme Administrative Law 196-209, Glazewski Environmental Law 108-122, and Hoexter and Lyster Constitutional and Administrative Law 5560 . 
32 of the 1996 Constitution. ${ }^{60}$ Information may include any information held by the state that may have an impact on an aggrieved person invoking this right. ${ }^{61}$ Hence, information in this context may specifically relate to information used during, or for the sake of, decision-making, including policies and criteria used by administrative bodies. ${ }^{62}$ In this sense, section 32 displays interrelatedness with the provisions on administrative justice in section 33 of the 1996 Constitution. Inaccessible information held by, for example the DEAT, which was used during the assessment of an environmental authorisation, may be demanded by an affected developer who feels that his or her right to administrative justice has been infringed, due to unreasonable delay during the decision-making process. ${ }^{63}$ The close connection between these two rights was reaffirmed in Aquafund $v$ Premier of the Western Cape ${ }^{64}$ where it was stated that:

... a person must be entitled to such information as is reasonably required by him to determine whether his right to lawful administrative action has been infringed or not. If a person is not able to establish whether his rights have thus been infringed, he will clearly be prejudiced. ${ }^{65}$

Access to information held by the state may be particularly relevant in environmental context. ${ }^{66}$ This is attributed to the notion that administrative decision-making, and consideration of certain technical criteria, policy consideration and so forth, may have a direct or indirect bearing on the environment and developers who are involved with

60 The right of access to information not only includes a right of access to information held by the state, but also to access of information held by another person that is required for the exercise or protection of any rights. See s 32(b) of the 1996 Constitution. The rationale behind the right of access to information is arguably to foster a culture of accountable governance, since government can be held accountable and liable on the basis of explanations for any governmental actions. This right also articulates the notion of open democracy that closely correlates with the aforementioned. See in this regard Devenish, Govender and Hulme Administrative Law 181, 187. For an insightful discussion of the right to access to information and some aspects of the PATIA, see O'Regan "Democracy and Access to Information" 11-16; Govender "Assessment of Limitation on Access to Information" 17-28; and Klaaren, Currie and Smith "Foreign Access to Information" 29-40.

61 De Waal, Currie and Erasmus Bill of Rights Handbook 526.

62 Ibid 526.

63 For a further discussion on the impact of the right to access to information on other rights, see Devenish, Govender and Hulme Administrative Law 194-196.

64 Aquafund v Premier of the Western Cape 19977 BCLR 907 (C).

65 Ibid at $916 \mathrm{E}$.

66 Glazewski Environmental Law 111-112. See for a comprehensive discussion of the right to access to environmental information, Du Plessis SALJ 222-244; Du Plessis 1998 SAJELP 116-139; Du Plessis 1999 JCRDL 352-372; Du Plessis 1999 Stell LR 36-55; Du Plessis 1999 Obiter 92-112; and Ferreira-Snyman and Du Plessis 2002 Koers 387-404. 
infrastructural developments. ${ }^{67}$ There is no distinction made in the PATIA between general information and environmental information. ${ }^{68}$ The PATIA does however mention "public safety or environmental risk"69 in sections 36(2)(c), 42(5)(c), 46(a)(ii), 68(2) and 70(1) thereof, which is in most cases more applicable to commercial information held by private bodies and third parties such as industry, and not necessarily organs of state. ${ }^{70}$

The NEMA however significantly extends the right to access to information provided in the PATIA to environmental matters. Section 2(4)(k) of the NEMA specifically provides that "...[d]ecisions must be taken in an open and transparent manner, and access to information must be provided in accordance with the law." ${ }^{71}$ Section 31(1)(a) of the NEMA provides in addition that:

... every person is entitled to have access to information held by the State and organs of state which relates to the implementation of this Act and any other law affecting the environment, and to the state of the environment and actual and future threats to the environment, including any emissions to water, air or soil and the production, handling, transportation, treatment, storage and disposal of hazardous waste and substances.

Although section 31(1) states that access to environmental information will be regulated by the PATIA, the act, in section 6 read together with schedule 1, preserves section 31 of the NEMA. ${ }^{72}$

It can be deduced from the above that, in addition to the right to administrative justice and access to courts, any aggrieved developer who suffers at the hands of an

67 See the example of water use license under ch 4 of the National Water Act 36 of 1998 discussed in par 2 above. See also for a more general discussion Du Plessis 1998 SAJELP 115-139.

$68 \mathrm{~S} 9$ of the PATIA.

69 "Public safety or environmental risk" is defined in s 1 as: "...harm or risk to the environment or the public (including individuals in their workplace) associated with-

(a) a product or service which is available to the public;

(b) a substance released into the environment, including, but not limited to, the workplace;

(c) a substance intended for human or animal consumption;

(d) a means of public transport; or

(e) an installation or manufacturing process or substance which is used in that installation or process.

70 Glazewski Environmental Law 112.

71 It is significant that access to information is provided for in s 2 of the NEMA. This section describes the national environmental management principles, which are applicable throughout SA to the actions of all organs of state. The NEMA therefore recognises the importance of access to information for the successful functioning of, not only environmental management and governance, but also for the achievement of the objectives of the act as a whole. 
inefficient environmental administration, may also rely on his or her right to access to information. ${ }^{73}$ The application of this right in environmental context, has significantly been enhanced by the provisions of the NEMA. This may arguably contribute to a more comprehensive protection of the rights of any aggrieved developer.

\subsection{The right to a wide legal standing}

The right to a wide legal standing, provided by section 38 of the 1996 Constitution, is also significant for the purpose of administrative justice. ${ }^{74}$ This right arguably aims to, inter alia, promote the possibility to enforce all constitutional rights, including the section 24 environmental right. In environmental context, it is noteworthy that the section 38 constitutional provisions on locus standi, have been significantly extended by section 32 of the NEMA. Section 32(1) states that:

Any person or group of persons may seek appropriate relief in respect of any breach or threatened breach of any provision of this Act, including a principle contained in Chapter 1 , or any other statutory provision concerned with the protection of the environment or the use of natural resources-

(a) in that person's or group of person's own interest;

(b) in the interest of, or on behalf of, a person who is, for practical reasons, unable to institute such proceedings;

(c) in the interest of or on behalf of a group or class of persons whose interests are affected;

(d) in the public interest; and

(e) in the interest of protecting the environment.

72 Glazewski Environmental Law 118.

73 It should be noted that although the developer currently has an extensive right to access to information, the relevant public authority may in certain instances refuse to divulge information. See in this regard s $7,12,33,35-45$ of the PATIA.

74 S 38 deals with the enforcement of rights and provides that:

Anyone listed in this section has the right to approach a competent court, alleging that a right in the Bill of Rights has been infringed or threatened, and the court may grant appropriate relief, including a declaration of rights. The persons who may approach a court are -

(a) anyone acting in their own interest;

(b) anyone acting on behalf of another person who cannot act in their own name;

(c) anyone acting as a member of, or in the interest of, a group or class of persons;

(d) anyone acting in the public interest; and

(e) an association acting in the interest of its members.

See for an in-depth discussion, Hoexter and Lyster Constitutional and Administrative Law 255275. 
In the first instance section 32(1) considerably extends the application of the section 38 constitutional clause to, not only include the rights contained in the Bill of Rights, but also to include-

... any breach or threatened breach of any provisions of this act [the $N E M A]$...or any other statutory provision concerned with the protection of the environment or the use of natural resources. ${ }^{75}$

Secondly, it may even be argued that apart from liberating public interest litigation, section 32(1)(e) extends the locus standi provisions, by providing that individuals or a group may currently act not only in their own interests, but also in the interest of the environment. $^{76}$ As far as 'having an interest in the relief sought' is concerned, it is significant that the environment is equated in terms of legal standing with individuals and groups. This may ultimately broaden the rights of developers and enhance environmental protection when the right to just administrative action is infringed.

\section{The Promotion of Administrative Justice Act}

Adhering to its constitutional obligation contained in section 33(3) of the 1996 Constitution, the legislator enacted the PAJA which came into operation on 30 November $2000 .^{77}$ The rationale of the PAJA is to place the primary right to administrative justice and the courts' powers of judicial review on statutory footing. ${ }^{78}$ Currently, administrative justice is mainly derived from the provisions of the PAJA and not the constitutional provisions or the common law insofar as it deals with review of administrative action by a court, and the provision of an efficient administration. ${ }^{79}$ When asked to determine the scope, content and application of the

75 S 32(1) of the NEMA. See par 4 above for some of these acts that deal with the protection of the environment or the use of natural resources.

76 See in this regard Glazewski Environmental Law 121, 149-150.

$77 \mathrm{~S} \mathrm{33(3)} \mathrm{states} \mathrm{that} \mathrm{national} \mathrm{legislation} \mathrm{must} \mathrm{be} \mathrm{enacted} \mathrm{in} \mathrm{order} \mathrm{to} \mathrm{give} \mathrm{effect} \mathrm{to} \mathrm{the} \mathrm{rights}$ contained in s 33 of the 1996 Constitution.

78 By defining the rules and principles of administrative procedure, the PAJA aims to promote an efficient administration and good governance, and to establish a culture of accountability, openness and transparency in the public administration. See in this regard De Waal, Currie and Erasmus Bill of Rights Handbook 495-497 and Burns Administrative Law 10.

79 Dlamini states that the PAJA does not represent a complete codification of the common law. The latter will continue to function although it has been modified by the Constitution and partly codified by the PAJA. See in this regard Dlamini 2000 JSAL 71. 
right to administrative justice, the judiciary will however still heed constitutional and common law principles that give meaning to this right. ${ }^{80}$ The constitutionally entrenched right to just administrative action will therefore still continue to function alongside the provisions of the $P A J A .^{81}$

The PAJA contains a number of provisions that may be relevant for an aggrieved developer who seeks recourse when his or her right to administrative justice has been infringed by an environmental authority during environmental administration and governance procedures. ${ }^{82}$ Some of these provisions are discussed hereafter.

\subsection{Administrative action defined}

Administrative action is not defined in the 1996 Constitution. ${ }^{83}$ There are however a number of judgments that endeavoured to ascertain the meaning of administrative action in section 33(1) of the 1996 Constitution. ${ }^{84}$ Of particular relevance for the purpose of this article, is the judgment in President of the Republic of South Africa $v$ South African Rugby Football Union, ${ }^{85}$ where it was stated that the implementation of legislation amounts to an administrative action. When the meaning of administrative

80 Burns Administrative Law 10.

81 The main aim of the PAJA is to give effect to the provisions contemplated in s 33 of the 1996 Constitution which embodies the right to just administrative action. By defining the rules and principles of administrative procedure, the PAJA furthermore aims to promote an efficient administration and good governance and to establish a culture of accountability, openness and transparency in the public administration. This is in accordance with the provisions of the 1996 Constitution. See also Burns Administrative Law 10.

82 Amongst other things, the PAJA provides a more detailed exposition of the constitutional right to administrative justice, specific procedures that are applicable to the public administration, the grounds for judicial review, procedures for those who wish to challenge administrative action and procedures for the request of written reasons. Burns Administrative Law 10. It is proposed that these detailed provisions may greatly assists in clarifying practical procedures for the sake of seeking recourse by developers. This may strengthen the position of an aggrieved developer to a large extent.

83 See also par 4.1 above for a discussion of administrative action within the context of administrative justice.

84 These judgments include, inter alia, Premier Province of Mpumalanga of State-Aided Schools, Eastern Transvaal 19992 SA 91 (CC); Pharmaceutical Manufacturers Association of SA: In re Ex Parte President of the RSA 20002 SA 674 (CC); Permanent Secretary, Department of Education, Eastern Cape v Ed-U-College (PE) (Section 21) 20012 SA 1 (CC); Despatch High School v HEAD, Department of Education 20031 SA 246 (Ckh); Metro Inspection Services (Western Cape) $\checkmark$ Cape Metropolitan Council 19994 SA 1184 (C); Association of Chartered Certified Accountants v Chairman, Public Accountants' and Auditors' Board 20012 SA 980 (W); Claude Neon v Germiston City Council 19953 SA 710 (W); and Carephone v Marcus 199810 BCLR 1326 (LAC).

85 President of the Republic of South Africa $v$ South African Rugby Football Union 20001 SA 1 (CC). 
action in section 33(1) of the 1996 Constitution is accordingly required to be established, it can be derived from this judgment that where public officials in the public administration domain implements legislation, such as environmental authorisation requirements in terms of the ECA and the NWA, this will amount to administrative action. ${ }^{86}$

Administrative action is defined in the PAJA as meaning, inter alia:

... any decision taken, or any failure to take a decision, by-

(a) an organ of state, when-

(i) exercising a power in terms of the Constitution or a provincial constitution; or

(ii) exercising a public power or performing a public function in terms of any legislation; or

(b) a natural or juristic person, other than an organ of state, when exercising a public power or performing a public function in terms of an empowering provision,

which adversely affects the rights of any person and which has a direct, external legal effect. ${ }^{87}$

Burns $^{88}$ is of the opinion that this definition is inadequate and unsatisfactory, since it does not clearly delineate what administrative action is. ${ }^{89}$ She points out a number of discrepancies with regard to the definition of administrative action in relation to further provisions of the PAJA. These include: that the definition mentions rights and not legitimate expectations, although legitimate expectations is provided for in section 3 of the PAJA; and that the definition refers to rights that are adversely affected, while section 3 provides for rights or legitimate expectations that are materially and adversely affected. ${ }^{90}$ It is additionally argued that the definition severely limits the constitutional right to just administrative action, ${ }^{91}$ which, when considered in the context of the bold aims of the PAJA, is an unfortunate state of affairs.

86 See par 3 above.

$87 \mathrm{~S} 1$ of the PAJA.

88 Burns Administrative Law 20.

89 Hoexter and Lyster Constitutional and Administrative Law 91-113.

90 A positive attribute of this definition is that it indicates what is not included within the ambit of administrative action by providing for a number of exclusions which mainly deal with the executive authority of national, provincial and local authorities. Burns Administrative Law 20.

91 Hoexter and Lyster Constitutional and Administrative Law 100, 
Administrative decision-making is central to administrative justice and hence, administrative action. The definition of "decision" in the PAJA accordingly stands in close relationship with administrative action as defined in the act. Decision is defined in section 1 as including:

... any decision of an administrative nature made, proposed to be made, or required to be made, as the case may be, under an empowering provision, including a decision relating to-

(a) making, suspending, revoking or refusing to make an order, award or determination;

(b) giving, suspending, revoking or refusing to give a certificate, direction, approval, consent or permission;

(c) issuing, suspending, revoking or refusing to issue a licence, authority or other instrument;

(d) imposing a condition or restriction;

(e) making a declaration, demand or requirement;

(f) retaining, or refusing to deliver up, an article; or

(g) doing or refusing to do any other act or thing of an administrative nature.

This definition exudes the actions normally associated with administrative decisionmaking, which can also be found in the process of implementing environmental legislation such as the NWA and the ECA. It is noteworthy that the definition specifically provides for giving, suspending, revoking or refusing to give a certificate, direction, approval, consent or permission; issuing, suspending, revoking or refusing to issue a licence; or imposing a condition or restriction. These decision-making procedures are especially apparent in environmental administration, where authorisations are issued, suspended or revoked; and conditions and restrictions imposed on developers who carry out activities that may have an adverse affect on the environment. This definition, read together with the definition of administrative action, furthermore includes any failure to take a decision by the relevant environmental authority.

It is clear from the definition that the decision must be of an administrative or public law nature. This describes a relationship of inequality or subordination that exists 
between the state and the individual. ${ }^{92}$ The decision must also be made in terms of an empowering provision such as legislation, from which governmental power is derived. This decision must be taken by, inter alia, an organ of state which may include governmental departments such as the DEAT and DWAF, as well as officials within these departments. ${ }^{93}$ It is also a requirement that the rights of the individual must have been adversely affected. ${ }^{94}$ Burns ${ }^{95}$ states in this regard that one should rely on the determination theory, ${ }^{96}$ as well as the deprivation theory when the rights of an individual that may be affected, are ascertained. ${ }^{97}$ Both these theories should apply when the rights of, for example an aggrieved developer, are established. This argument is supported by the socio-economic nature of some fundamental rights, such as the right to an environment that is not harmful to health and well-being. ${ }^{98}$ It is argued that for an individual to benefit from socio-economic rights, it is imperative that the determination theory should also apply in order to enforce and realise these rights. ${ }^{99}$ Rights should furthermore include rights derived from the common law, ${ }^{100}$ customary law and legislation. ${ }^{101}$ The decision should in the last instance also have a direct external legal effect. This means that an aggrieved developer may approach a court where prejudice on the part of the administrator is evident or where mala fides are apparent during decision-making. ${ }^{102}$

92 Burns Administrative Law 22.

93 Ibid 23.

94 See also for an in-depth discussion Hoexter and Lyster Constitutional and Administrative Law 103-107.

95 Burns Administrative Law 28-29.

96 The determination theory describes the situation where the rights that and individual would have if she is for example granted a license in terms of an empowering provision, are determined. It therefore does not relate to existing rights, but to some future rights that may be obtained if a decision is made. Burns Administrative Law 27-28.

97 The deprivation theory relates to those instances where an individual is deprived of some existing right or benefit because of a decision made. Burns Administrative Law 28-29.

98 See par 2 above.

99 Burns Administrative Law 29.

100 An example of rights deduced from common law in environmental context, include those rights that are established in terms of neighbour law and the law of nuisance. The operative common law principle in this instance is sic utere tuo ut alienum non laedas, which may be relied on where an industrial plant causes noise pollution or bad odours that affect a community situated close to an industrial plant. Glazewski Environmental Law 12.

101 See s 39(3) of the 1996 Constitution which states that "[t]he Bill of Rights does not deny the existence of any other rights or freedoms that are recognized or conferred by common law, customary law or legislation..."

102 Burns is of the opinion that the phrase "direct external legal effect" severely limits the scope of the right to administrative justice, by contending that it is questionable whether this phrase will pass constitutional scrutiny. Burns Administrative Law 29-31. See also Hoexter and Lyster Constitutional and Administrative Law 107-110. 
It can be deduced that the definition of administrative action and decision, will include those decisions made and administrative actions performed within the empowering provisions of environmental legislation, such as the ECA and the NWA. The developer has certain rights which include both existing rights and rights that she may have if she is for example granted a water use licence under the NWA. Where the developer experiences mala fides or prejudice from the relevant environmental authority during the decision-making process, she will also be entitled to approach a court of law to enforce his or her right to administrative justice.

\section{$5.2 \quad$ Judicial control through review}

Hoexter and Lyster ${ }^{103}$ indicate that South African courts have always played, and will continue to play, a crucial role in overseeing the activities of the administration. The judiciary supervises the administration by way of judicial review which is provided for by, inter alia, section 33 of the 1996 Constitution, the PAJA, ${ }^{104}$ and special statutory review. ${ }^{105}$ Judicial review essentially describes the judiciary's-

... power to scrutinise administrative decisions and, where appropriate, to set them aside or correct them. ${ }^{106}$

Judicial review in South Africa is firmly based on constitutional provisions, which include legality and the duty to protect constitutional rights. ${ }^{107}$

Of practical relevance for any developer will be the provisions of section 6 of the PAJA. Section 6(1) provides that-

... any person may institute proceedings in a court or a tribunal for the judicial review of an administrative action. ${ }^{108}$

103 Hoexter and Lyster Constitutional and Administrative Law 36-37. Administrative appeals may also provide effective measures for challenging the administration on the basis of the merit of a decision. Judicial review on the other hand tests the legality of the decision. Administrative appeals may also be specifically advantageous when compared with judicial review, since these procedures are cheaper and faster than litigation, and administrative authorities arguably have the necessary expertise to judge decisions made by administrative bodies. See further Hoexter and Lyster Constitutional and Administrative Law 37-41.

104 S 6-8 of the PAJA.

$105 \mathrm{Eg}$ the PATIA.

106 Hoexter and Lyster Constitutional and Administrative Law 77.

107 S 8 and 39 of the 1996 Constitution. 
This may arguably also include any developer who's right to administrative justice has been adversely affected by the relevant environmental authority. The remainder of section 6 sets out the grounds for judicial review in a comprehensive fashion by providing for various instances where an aggrieved developer may approach a court of law for the review of administrative action. ${ }^{109}$ These provisions may arguably enhance the remedies at the disposal of any developer who feels that his or her development application has been, inter alia, unlawfully and unreasonably dealt with.

It is also for these reasons, and other reasons discussed below, that judicial precedent may be especially important for aggrieved developers who want to assert their right to, inter alia, administrative justice. Based on the discussion in paragraph 6 below, it is argued that judicial review of administrative action, may be a useful remedy in the hands of developers who are being adversely affected by maladministration.

\section{An analysis of recent case law}

The reliance on jurisprudence for the development of administrative justice should not be underestimated since,

... the creative and innovative role of the courts in relation to inter alia [sic] administrative law jurisprudence should significantly enhance the cause of administrative justice. ${ }^{110}$

Two recent judgments in the South Eastern Cape Local Division may provide some guidance as to the application of administrative justice in the context of administrative functions performed in terms of matters relating to the environment. These judgments do not specifically relate to administrative justice in terms of environmental administration and environmental governance. The judgments furthermore do not specifically address the right to dispute settlement, the right to access to information, and the right to a wide legal standing. These judgments rather focus on the right to administrative justice. However, as has been argued above, the rights to access to

$108 \mathrm{~S} 6$ of the PAJA should be read together with s 7 of the act that sets out the procedure of judicial review.

109 S 6(2)-6(3). 
information, dispute settlement, and a wide legal standing, stand in close correlation with the right to administrative justice. ${ }^{111}$ Hence, it is argued, that the importance the court places on the right to administrative justice, may be an indication that other constitutional rights closely connected to the section 33 right, may in future be regarded in an equally important light whenever these rights are invoked to protect against maladministration.

Based on the merit of the applicability of administrative justice to environmental administration and governance, these judgments may go a long way to further enhance the concept of administrative justice from a judicial point of view. ${ }^{112}$ The court's approach to maladministration and insufficiency in the public administration domain may be proof that administrative injustice within the ranks of environmental authorities, as was the case in these judgments, will not be tolerated. This may significantly advance the case of any aggrieved developer who's right to administrative justice and accompanying rights have been infringed.

\subsection{Mahambehlala v MEC for Welfare, Eastern Cape and Another}

In the recent case of Mahambehlala $v$ MEC for Welfare, Eastern Cape and Another, ${ }^{113}$ the applicant instituted legal proceedings against the MEC for Welfare in the Eastern Cape, by contending, inter alia, that her right to just administrative action was infringed in terms of section 33 of the 1996 Constitution.

\subsubsection{Facts of the case}

In terms of section 2(a) of the Social Assistance Act 59 of 1992, the Director General: Welfare of the Eastern Cape Provincial Government, is empowered to make social grants to disabled persons who qualify for such grants under the provisions of the act. Certain regulations were published in 1998 to provide for the manner in which applications for grants were to be made, the approval or refusal of any application, as well as the date of accrual of any approved grant. ${ }^{114}$ The applicant properly applied

110 Devenish, Govender and Hulme Administrative Law 15.

111 See par 4 above.

112 See par 2 and 3 above.

113 Mahambehlala v MEC for Welfare, Eastern Cape 20021 SA 342 (SECLD).

114 GN R418 GG of 31 March 1998. 
for a social grant on 7 March 2000 in terms of the regulations. A period of nine months lapsed during which time no response from the Department of Welfare was received. The applicant therefore instituted proceedings to compel the second respondent to, inter alia, consider the application, commence payment of the grant on the basis that it had been approved on 7 June 2000, pay interest on the amount in arrears, as well as an order to oblige the first respondent to continue payment on a monthly basis, and an order directing the second respondent to furnish reasons in the event that the application was refused. Following an order by consent, the Regional Director of the Department of Welfare in Port Elizabeth stated that the applicant's application for a disability grant had been approved on 9 November 2000. The only issues left to be decided were the declaratory order determining the actual date of accrual of the grant, as well as the contention by the applicant that her fundamental right to just administrative action in terms of section 33(1) of the 1996 Constitution had been infringed. ${ }^{115}$

\subsubsection{Argument of the court}

The applicant contended that, by delaying the approval of her application for a social grant, the respondent infringed her fundamental right enshrined in section 33(1) of the 1996 Constitution that espouses the right to administrative action that is lawful, reasonable and procedurally fair. ${ }^{116}$ The argument in this regard is founded upon the contention that a period of three months would have been a "more than reasonable time" for the second respondent to have applied his mind to the matter and reached a decision.

In its assessment of the matter before it, the court stated that:

...common sense tells one that in a case such as this where no unduly intricate investigations have to be made, a period of three months would normally be more than sufficient to take an administrative decision. In any event, if it was not, one would certainly have expected the respondent to detail why such a period would not be reasonable. ${ }^{117}$

115 For the purpose of this article, only the issue relating to just administrative action is discussed. 116 At 351F.

117 At 351I. 
It also added that when the applicant instituted proceedings against the respondent, it took virtually no time at all for her application to be processed. ${ }^{118}$ This led the court to believe that it was the institution of the proceedings that led to the expeditious processing of her application and not the-

... administrative sloth and inefficiency which currently bedevils the Department of Welfare of the Eastern Cape. ${ }^{119}$

With this statement the court rejected contentions by the respondent that lack of resources and infrastructure led to the unreasonable delay, and further reaffirmed that in the absence of adequate reasons given by the respondent to justify the delay, no conclusion could be reached that the delay was indeed reasonable.

The respondents also contended that the amalgamation of a number of different social security systems from the previous administration led to the delay in the application being processed. The court however held that the respondents failed to explain how the amalgamation resulted in the delay and furthermore stated that there-

... is today but a single department in the Eastern Cape responsible for the administration of the applicant's application. ${ }^{120}$

The court added that because the respondents could not explain the delay of nine months, it cannot be expected from the applicant to know what led to the delay. The court accordingly found that if the applicant's application of 7 March 2000 had been reasonably dealt with, it would have been approved by no later than 7 June 2000 which is five months before it was finally approved on 9 November $2000{ }^{121}$

Having found that the delay in approving the grant was indeed unreasonable, the court proceeded to decide whether the right of the applicant to just administrative action has been infringed. In this respect the court relied on a dictum of Van Zyl j in Vulindlela Furniture Manufacturers v MEC, Department of Education and Culture, Eastern 
Cape. ${ }^{122}$ By commenting on section 24 of the Constitution of the Republic of South Africa 200 of 1993 (hereafter the Interim Constitution) that also enumerates the right to just administrative action, Van Zyl j stated that:

...the essence of the applicant's case in the present matter is that the respondents have failed to comply with their statutory duty, and not that they have failed to follow or adopt procedures which are "right and just and fair". The only other section which may find application in the present matter is $\mathrm{s}$ 24(a). This section entitles every person to lawful administrative action where any of his or her rights or interests are affected or threatened. "Administrative action" should in my view not be limited to administrative acts or decisions but should also include the failure by a body exercising public power to act where it has a duty to act. "Lawful administrative action" is wide enough to also include an omission to take administrative action where such a duty is imposed. ${ }^{123}$

The present court concurred with the above view and stated that failure to take administrative action where there is a duty to take such action, would not constitute lawful administrative action, and would consequently infringe on the right contained in section 24 of the Interim Constitution. ${ }^{124}$ The court consequently found that section 24 of the Interim Constitution and section 33(1) of the 1996 Constitution contain similar terms. Seen in this context, the court construed that a failure to take administrative action where such a duty exists, constitutes an equal infringement of the right to just administrative action as in those instances where an application is unreasonably refused. ${ }^{125}$ With reference to the failure to take the decision within a reasonable time, the court came to the conclusion that the applicant's right to just administrative action had been unlawfully and unreasonably infringed. ${ }^{126}$

The court in the final instance proceeded to assess whether the applicant would be entitled to appropriate relief due to the infringement of a fundamental right, as set out in section 38 of the 1996 Constitution. ${ }^{127}$ In a lengthy argument, the court reiterated the fact that the current constitutional provisions effectively subsumed the common-

122 Vulindlela Furniture Manufacturers v MEC, Department of Education and Culture, Eastern Cape 19984 SA 908 (Tk) at 930F-H.

123 At 352I-353A.

124 At 353B.

125 At 353C.

126 At 353D.

127 S 38 of the 1996 Constitution provides that: "Anyone listed in this section has the right to approach a competent court, alleging that a right in the Bill of Rights has been infringed or threatened, and the court may grant appropriate relief, including a declaration of rights." See also par 4.2 above. 
law principles pertaining to judicial review. ${ }^{128}$ On the basis of available common-law remedies, the court was in the position to substitute the decision of the second respondent for its own, although the latter option would have been made with some reluctance. However, since the second respondent had no legal mandate to approve a grant retrospectively, the court argued that it does not have the powers to order the payment of the grant with retrospective effect. ${ }^{129}$ The result of this interpretation essentially meant that "...the applicant's common-law remedies are insufficient to be regarded as appropriate relief as envisaged by s 38 of the Constitution...", ${ }^{130}$ and that it was the duty of the court to fashion an appropriate remedy which it describes as constitutional relief. By drawing support from the remarks of Froneman j in Ngxuza $v$ Permanent Secretary, Department of Welfare, Eastern Cape, ${ }^{131}$ the court recognised the need for a remedy for administrative justice which:

...should be determined against the background of a large proportion of the people living in this province being poor, access to legal assistance being limited and the necessary financial assistance to take an unhelpful and unresponsive public administration to court being problematic. ${ }^{132}$

The court accordingly granted what it termed "constitutional relief". Constitutional relief in this instance means that it would be just and equitable for an aggrieved person in the position of the applicant to be placed in the same position in which she would have been, had her fundamental right to lawful and reasonable administrative action not been infringed. ${ }^{133}$ Constitutional relief that places the applicant in such a position, would be considered "appropriate" as envisaged by the 1996 Constitution.

\subsection{Mbanga $v$ MEC for Welfare, Eastern Cape and Another}

The case of Mbanga $v$ MEC for Welfare, Eastern Cape and Another, ${ }^{134}$ ran simultaneously with the Mahambehlala case. The facts of both cases are very similar. The case of Mbanga involves the applicant applying for relief based on, inter alia, the

128 At 353G-354E.

129 At 354E-H.

130 At 355B-C.

131 Ngxuza v Permanent Secretary, Department of Welfare, Eastern Cape 200012 BCLR 1332 at $1329 \mathrm{H}-\mathrm{I}$.

132 At 355G-H.

133 At 357 G-H.

134 Mbanga v MEC for Welfare, Eastern Cape 20021 SA 359 (SECLD). 
fact that his right to just administrative action, as envisaged in section 33 of the 1996 Constitution, has been infringed.

\subsubsection{Facts of the case}

On 10 March 1998 the applicant properly applied for a social grant in terms of the Social Assistance Act 59 of 1992 and the accompanying regulations. ${ }^{135}$ No response was received from the Department of Welfare for more than two and a half years and the applicant instituted proceedings on 11 October 2000.

The applicant claimed relief including: that the second respondent, or the appropriate official in his department, be ordered to consider and decide upon the applicant's application for a social grant; that in the event of the second respondent approving the applicant's application for a social grant, the first respondent be ordered to commence payment thereof with effect from 10 March 1998, within 15 days after the date of the order, and to continue such payments on a monthly basis thereafter for as long as the applicant qualifies for such payments in terms of the relevant laws; and to pay interest on arrears. The applicant furthermore claimed that in the event of the DirectorGeneral refusing the applicant's approval for a social grant, the second respondent is ordered to provide reasons for the decision taken, and that the second respondent pays the costs of this application. Following agreement by the parties on some of the aforementioned issues, a remaining matter had to be addressed by the court, namely the contention by the applicant that his right to just administrative action has been infringed in terms of section 33 of the 1996 Constitution.

\subsubsection{Argument of the court}

As in the case of Mahambehlala, the court found in this instance that the period of 32 months it took for a decision to be made by the respondent was unreasonable. ${ }^{136} \mathrm{~A}$ reasonable period for a decision on an application for a social grant to be taken would rather be three months. Hence, the failure to take a decision consequently amounted to 
a gross infringement of the applicant's constitutional right to lawful and just administrative action. ${ }^{137}$

The court further emphasised that these two cases are not isolated incidents of administrative inefficiency but that they "... rather appear to be the tip of the iceberg". ${ }^{138}$ A further speculation is made by the court on the escalating costs liability incurred by the Department of Welfare of the Eastern Cape, which includes substantial amounts of money, ultimately straining the public purse due to administrative inefficiency. ${ }^{139}$ In a strongly-worded dictum the court declares that:

...public funds are going to continue to be wasted solely because public officials do not do the work which they are being paid to do. This is an intolerable state of affairs. Public servants are, as their very name implies, there to serve the public: not to sit inert and mobile, doing little apart from drawing their salaries and pensions [own emphasis]. It is truly a disgrace that public servants in the employ of the Department of Welfare of this province are daily guilty of the widespread abuse of the human rights of others, rights enshrined in the Constitution which should zealously be protected and enforced. After all, they are charged by s 195(1)(e) of the Constitution to respond to people's needs. ${ }^{140}$

As with the Mahambehlala case, the court, in casu, ordered "constitutional relief" to be afforded which essentially aims to place the applicant in the same position in which he would have been had his fundamental right to lawful and reasonable administrative action not been infringed. ${ }^{141}$

\subsection{Some comments}

A number of aspects came to the fore in the above judgments. In the first instance, it is clear that the court will assess the content of the right to just administrative action with reference to all the surrounding circumstances involved in the matter before it. It will take into account, inter alia, the urgency of the matter, historical perspectives, circumstances surrounding aggrieved individuals, current practice in state

137 At 369A.

138 At 369G.

139 At 269I.

140 At 369J-370B.

141 At $370 \mathrm{H}$ and par 6.1.2 above. 
administration, the attitude of individuals involved in state administration, and the possible future effect of its judgment on administrative practices.

Secondly, it is apparent that the court will not attribute much weight to contentions that administrative practices are inefficient due to lack of resources and infrastructure, or problems inherited from the pre-1994 government. It is evident that the protection of the fundamental rights of individuals is of far greater importance to the court. These fundamental rights may not only include the right to just administrative action, but also the right to dispute settlement, the right to access to information, and the right to a wide legal standing. ${ }^{142}$ Based on the emphasis of the importance to uphold the right to administrative justice in these judgments, it is accordingly proposed that the judiciary may in future attribute the same credence to other fundamental rights that aim to protect the developer from maladministration by the state.

Thirdly, the court emphasises the present judicial attitude towards an inefficient state administration. ${ }^{143}$ In no unclear terms the court states that it will not tolerate inefficient administration by public officials in those instances where the fundamental rights of individuals may be infringed by the attitude and conduct, or non-conduct, of such officials. This may particularly contribute to the establishment of judicial precedents that may make it increasingly difficult for the state administration to hide behind excuses that are intolerable in a modern constitutional dispensation where the protection of fundamental human rights should be paramount.

It is proposed that these judgments may be of great assistance to affected individuals whose rights have been infringed in the realm of administrative actions performed by environmental governance bodies. Where a developer, for example, apply for an authorisation in terms of the provisions of the ECA or the NWA, it may be expected that courts will arguably find in favour of the developer where the application is unreasonably delayed, or where there are mala fides, or prejudice on the part of the environmental authority. This may in addition contribute to the remedies that a developer has where he or she suffers, for example, financial loss because of

142 This submission is based on the notion that there exists a close relationship and interrelatedness between the right to administrative justice, the right to dispute settlement, the right to access to information, and the right to a wide legal standing. See par 4 above.

143 This is done with specific reference to the Department of Welfare of the Western Cape. 
infrastructural development that can not proceed before the relevant environmental authorisations have been granted. If these judgments are an indication of future judicial developments with regard to the issue of unjust administrative action, it may be expected that the rights of developers will be more adequately protected when having to deal with environmental governance bodies. This may additionally imply that by executing environmental governance that is firmly based on the principles of just administrative action, the state will adhere to its constitutional obligation as enumerated in, inter alia, sections 24 and 33 of the 1996 Constitution.

\section{$7 \quad$ Conclusion}

While developers are currently given the mandate and legislative support to conduct development, there exist a number of inhibiting circumstances in the development decision-making process. As in any functionary of government, unjust administrative actions by environmental authorities often result in time and financial constraints for the developer. This may have a significant detrimental affect on development initiatives and measures undertaken by government to protect the environment. The fundamental right to just administrative action as well as accompanying rights and legislative provisions on administrative justice may however greatly influence this state of affairs.

It has been argued in this article that there is a close relationship between just administrative action and environmental concerns. The state is primarily responsible for the execution of environmental governance in such a way that would realise the right to have the environment protected, for the benefit of present and future generations through reasonable legislative and other measures. Administrative justice in this sense may contribute significantly to the protection of the rights of the developer and the fundamental right relating to the environment.

It is proposed that developers can, and henceforth should, rely on constitutional and legislative provisions and judicial precedents, that oblige administrative organs to conduct administrative decision-making in a reasonable and just way. 


\section{Bibliography}

Bosman Waste Disposal

Bosman C Waste Disposal or Discharge: A Harmonised Regulatory Framework Towards Sustainable Use (MSc Environmental Management Dissertation PU for CHE 1999)

Burns Administrative Law

Burns Y Administrative Law under the 1996 Constitution $2^{\text {nd }}$ ed (LexisNexis Durban 2003)

Devenish, Govender and Hulme Administrative Law

Devenish GE, Govender K and Hulme D Administrative Law and Justice in South Africa (Butterworths Durban 2001)

De Waal, Currie and Erasmus Bill of Rights Handbook

De Waal J, Currie I and Erasmus G The Bill of Rights Handbook $4^{\text {th }}$ ed (Juta Landsdowne 2001)

Dlamini 2000 JSAL

Dlamini CRM "The right to administrative justice in South Africa: Creating an open and accountable democracy" Part 22000 JSAL 53-71

Du Plessis 1998 SALJ

Du Plessis W "Omgewingsinligting in die Europese Gemeenskap" 1998 (2) SALJ 222-244

Du Plessis 1998 SAJELP

Du Plessis W "Right to Environmental Information in the USA" 1998 SAJELP $115-139$

Du Plessis 1999 JCRDL

Du Plessis W "Reg op Omgewingsinligting in Duitsland" 1999 (62:3) JCRDL 352-372

Du Plessis 1999 Stell LR

Du Plessis W "'n Reg op Omgewingsinligting in Nederland" 1999 Stell LR 36 


\section{Du Plessis 1999 Obiter}

Du Plessis W "Enforcement of Environmental Rights by way of a Right to Information" 1999 (20) Obiter 92-112

Ferreira-Snyman and Du Plessis 2002 Koers

Ferreira-Snyman A and Du Plessis W "Grondwetlike Waardes, die Openbare Administrasie en die Reg op Toegang tot Omgewingsinligting" 2002 (67:4) Koers 387-404

Glazewski Environmental Law

Glazewski J Environmental Law in South Africa (Butterworths Durban 2000)

Glazewski Environment

Glazewski J "Environment" in Cheadle MH, Davis DM and Haysom NRL (eds)

South African Constitutional Law: The Bill of Rights (Butterworths Durban 2002) 413

Govender K "Assessment of Limitation on Access to Information"

Govender K "An Assessment of Limitation on Access to Information in the Promotion of the Access to Information Act and the Danger that Disclosure will

Become the Exception Rather than the Norm" in Konrad Adenauer Stiftung

Seminar Report: The Constitutional Right of Access to Information 2001(5) 17-40

Hoexter and Lyster New Constitutional and Administrative Law

Hoexter C and Lyster R The New Constitutional and Administrative Law Vol 2 (Juta Cape Town 2002)

Klaaren, Currie and Smith "Foreign Access to Information Legislation"

Klaaren J, Currie I and Smith A "Analysing Foreign Access to Information

Legislation from a South African Viewpoint" in Konrad Adenauer Stiftung

Seminar Report: The Constitutional Right of Access to Information 2001(5) 29-40

Kotzé and Van der Walt 2003 SAJELP

Kotzé LJ and Van der Walt AJ "Just Administrative Action and the Issue of Unreasonable Delay in the Environmental Impact Assessment Process: A South African Perspective" 2003 SAJELP 39-66 
Nel and Du Plessis "Unpacking Integrated Environmental Management"

Nel J and Du Plessis W "Unpacking Integrated Environmental Management: a

Step Closer to Effective Co-operative Governance?" in IAIAsa Conference

Proceedings: Co-operative Governance in South Africa: The Search for the Holy

Grail 1-3 September 2003 George, South Africa (2003) 89

O'Regan "Democracy and Access to Information"

O'Regan K "Democracy and Access to Information in the South African

Constitution: Some Reflections" in Konrad Adenauer Stiftung Seminar Report:

The Constitutional Right of Access to Information 2001(5) 11-16

\section{Register of Legislation and Government publications}

Constitution of the Republic of South Africa 1996

Constitution of the Republic of South Africa 200 of 1993

Environment Conservation Act 73 of 1989

GN R418 Government Gazette of 31 March 1998

Marine Living Resources Act 18 of 1998

Mineral and Petroleum Resources Development Act 28 of 2002

National Environmental Management Act 107 of 1998

National Forests Act 84 of 1998

National Heritage Resources Act 25 of 1999

National Nuclear Energy Regulator Act 47 of 1999

National Veld and Forest Fire Act 101 of 1998

National Water Act 36 of 1998

Nuclear Energy Act 46 of 1999

Promotion of Administrative Justice Act 3 of 2000

Promotion of Access to Information Act 2 of 2000

R 1182 Government Gazette 18261 of 5 September 1997

R 1183 Government Gazette 18261 of 5 September 1997

R 1184 Government Gazette 18261 of 5 September 1997

Social Assistance Act 59 of 1992

Water Services Act 108 of 1997 


\section{Register of Cases}

Association of Chartered Certified Accountants v Chairman, Public Accountants' and Auditors' Board 20012 SA 980 (W)

Aquafund (Pty) Ltd v Premier of the Western Cape 19977 BCLR 907 (C)

Carephone (Pty) Ltd v Marcus 199810 BCLR 1326 (LAC)

Claude Neon Ltd v Germiston City Council 19953 SA 710 (W)

Despatch High School v HEAD, Department of Education 20031 SA 246 (Ckh)

Mahambehlala v MEC for Welfare, Eastern Cape and Another 20021 SA 342

(SECLD)

Mbanga v MEC for Welfare, Eastern Cape and Another 20021 SA 359 (SECLD)

Metro Inspection Services (Western Cape) CC v Cape Metropolitan Council 19994 SA $1184(\mathrm{C})$

Ngxuza and Others v Permanent Secretary, Department of Welfare, Eastern Cape, and Another 200012 BCLR 1332

Permanent Secretary, Department of Education, Eastern Cape v Ed-U-College (PE) (Section 21) Inc 20012 SA 1 (CC)

Pharmaceutical Manufacturers Association of SA: In re Ex Parte President of the RSA 20002 SA 674 (CC)

Premier Province of Mpumalanga of State-Aided Schools, Eastern Transvaal 19992 SA 91 (CC)

President of the Republic of South Africa v South African Rugby Football Union 2000 1 SA 1 (CC)

Vulindlela Furniture Manufacturers (Pty) Ltd v MEC, Department of Education and Culture, Eastern Cape, and Others 19984 SA 908 (Tk) 